\title{
7. Determination of Antibody to Respiratory Pathogens
}

\author{
YA. S. SCHWAR'TZMAN AND L. E. KAMFORIN
}

\section{INTRODUCTION}

Qualitative evaluation and quantitative determination of antibody to respiratory pathogens represents a substantial part of research and applied virology. These investigations can serve quite different purposes. Epidemiologists need the serological data necessary for the control of influenza and other respiratory infections and for elucidating aetiological peculiarities of past infections. A system of constant surveillance of influenza morbidity and seroepidemiological status of the population has been organized in the USSR. The herd immunity is assessed as to circulating influenza viruses and some older strains which have gone out of circulation. The results obtained are important not only for current epidemiological analysis, but also because they enable the prognosis, to some extent, of the epidemic process, the evaluation of danger in shift of influenza viruses when their reappearance in the circulation is anticipated, as was the case in 1976 in the USA and in 1977 in China and in the USSR.

Specialists who are developing new vaccines or improving existing ones are interested in determining the immunological status of those vaccinated. These results are essential for immunologists in order to elucidate mechanisms of humoral immunity. Based on serological information, the impact of chemoprophylactic and chemotherapeutic drugs on the immunological system can be evaluated. Determination of immune response to an infectious agent contributes essentially to a reliable diagnosis; as a result, the improvement of serological techniques is perpetuated in further investigations. It goes without saying that neither a single technique nor even a limited number of them can provide a solution to all the problems mentioned above.

The purpose of this review is consideration of the main serological techniques available and their application in serological investigations of acute respiratory infections.

\section{CONVENTIONAL TESTS}

The haemagglutination inhibition test (HIT) is still applied for serological 
diagnosis because many respiratory viral agents are characterized by haemagglutination activity which is inhibited by antiviral antibody and thus their activity can be measured by dilution. Haemagglutinating activity of the respiratory viruses is revealed with erythrocytes of various species: human influenza viruses agglutinate human, chicken and guinea pig erythrocytes. Parainfluenza viruses readily adsorb to and agglutinate erythrocytes within the same range of species as for parainfluenza 3 viruses, parainfluenza 1 type viruses-human (blood group I) and guinea pig erythrocytes, and parainfluenza 2 type viruses-human and chicken erythrocytes. Usually, erythrocytes of the guinea pig are used for HIT.

Adenoviruses are subdivided into four groups, according to their haemagglutination activity. Eighteen types of adenoviruses, including respiratory agents (types 3,7 ), belong to the first group which is characterized by agglutination of simian erythrocytes. The second group of adenoviruses (five types of adenoviruses) has the ability of rat erythrocyte agglutination but no respiratory virus belongs to this group. Some adenoviruses provoking respiratory infections are included in the third group, the specimens of which induce partial agglutination of rat erythrocytes. Adenoviruses of the last group do not agglutinate erythrocytes of these two animal species (Smorodintzev, 1985).

The passage history of the virus is not an important characteristic of haemagglutination activity. Thus, freshly isolated influenza viruses (H2N2) induce agglutination of human erythrocytes and only after several passages in chicken embryo do they begin to agglutinate chicken erythrocytes (Smorodintzev, 1985).

HIT is a comparatively simple reaction but it is sensitive to unspecific serum inhibitors. Special treatment of serum samples has been developed for inhibitors' inactivation. The choice of treatment method depends on the kind of virus used as well as on the serum species and on the type of inhibitor. Recombinants of influenza virus (H3N2) resistant to unspecific serum inhibitors are proposed for HIT (Fattal-German et al., 1980), or special diagnostic strains of influenza viruses are selected in the presence of unspecific serum inhibitors. The following methods for inactivation of unspecific serum inhibitors are known: RDE treatment, adsorption with chicken erythrocytes, sodium periodate treatment, inactivation at $56^{\circ} \mathrm{C}$ for $30 \mathrm{~min}$. The choice of a single technique or of combined techniques depends on the conditions of investigation.

Two modifications of HIT are known: macro- and microtechniques. The advantages of the latter test are evident, although some differences in the results of the two techniques are obtained. The antibody titres in the sera of immunized animals appear to be 2-3 times higher when the macrotechnique of HIT is used (Celedón et al., 1982). Study with monoclonal antibodies demonstrates that some groups neutralize infectivity but fail to inhibit haemagglutinating activity. Monoclonal antibodies that do not exert 
inhibition of this activity combine with determinants at the base of the globular head of the haemagglutinin molecule (Kida et al., 1982). These data suggest that only part of the antibody activity is evaluated in HIT, but an obvious advantage of the reaction is the ability to reveal strain-specific antibody to influenza $\mathrm{A}$ viruses in contrast to more modern and sometimes more sensitive diagnostic techniques which provide only type-specific serological diagnosis of the infection.

The sensitivity of HIT varies; it depends on the viral antigen used. Low sensitivity of the test for some influenza viruses (especially B) has spurred investigators to seek new techniques of viral antigen treatment. The treatment with Tween- $80(0.125 \%)$, and with ether for $15 \mathrm{~min}$, resulted in decrease of antibody titre to influenza A virus A/USSR/77 (H1N1), but increased the titre considerably to $\mathrm{A} / \mathrm{Bangkok} / 1 / 79(\mathrm{H} 3 \mathrm{~N} 2)$, and to some extent to $\mathrm{B} /$ Singapore $/ 79$, and produced no change in immunological activity to B/Hong-Kong/72 influenza virus (Profeta and Ballerini, 1981). The other investigations, while testing 80 serum samples from healthy persons, showed that ether treatment of influenza B strains B/Singapore/ $222 / 79$ and $B / H o n g-K o n g / 5 / 72$ increased only slightly the number of seropositive persons with the titre $\geqslant 40$ (from 0 and 4 samples to 6 and 7 ) (Mancini et al., 1983). The use of ether-treated antigen for HIT appears to be of little value. Nevertheless, it is still used in some investigations, and sensitivity of HIT is the highest, when compared with ELISA or the complement fixation test (CFT), according to some data (Hammond et al., 1980). No comparison with untreated antigen for HIT was made in this investigation.

Sensitivity of the HIT for serological diagnosis of influenza A infection is quite comparable with ELISA. The work was carried out by testing of paired sera from 455 patients (Julkunen et al., 1985). As for influenza B infection, ELISA gives better results when compared with HIT and CFT (59 vs. 40 for HIT and 37 for CFT). In another investigation, the sensitivity of HIT appeared to be considerably lower than in ELISA or neutralization test being equal to CFT sensitivity (95\% for ELISA, $81 \%$ for NT, $50 \%$ for HIT and CFT). This investigation was carried out during an outbreak of influenza A infection (H1N1) (Van Voris et al., 1985).

The serological investigation of 302 patients of younger age groups revealed maximal sensitivity for HIT $(25 \%)$ when compared with CFT $(8 \%)$, which can be explained by the pattern of immunological response of younger children (0-15 years old) (Hermsdorf, 1981). HIT is still in use as a reference technique in serological investigations for comparison with new serological methods (ELISA, radial haemolysis technique (RHT)). In all instances, a high correlation level was obtained in these studies, although the antibody titre in HIT was considerably lower than in ELISA (Schmidt $e t$ al., 1984; Murphy et al., 1981).

Serological diagnosis of influenza B infection by means of HIT was 
compared with RHT. In a group of 100 vaccinated people, seroconversion to influenza $B$ virus occurred in $27-54 \%$. The titre depends on the type of vaccine preparation used, while the titre of antibody in RHT ranged from $59 \%$ to $85 \%$ in the same groups of people vaccinated (Oxford et al., 1982). Higher sensitivity of RHT and NIT compared with HIT was also demonstrated in the investigation of 445 serum samples (Chakraverty, 1980).

A modified HIT was tested to compare it with a conventional test and $\mathrm{CFT}$ for the investigation of an outbreak of influenza in 1981-1982 and 1982-1983. For a modified HIT, ether-treated influenza B virus was used and the sensitivity of the test increased considerably, but the specificity of it decreased. Sensitivity of HIT is lower than in CFT $(52 \%$ and $93 \%$ respectively) (Pyhälä et al., 1985).

Comparison of HIT with ELISA for influenza B diagnosis has been carried out with serum samples from influenza reconvalescents. The antigen for both tests was prepared in the cells of green monkey kidney. The mean geometric titre of antibody was 16-71 in ELISA as compared with 3-10 for HIT (Turner et al., 1982).

Serological investigation of influenza $C$ infection was carried out on 842 serum samples from children and on 975 serum samples from adults by means of micromodification of HIT with influenza virus C/USSR/303/77 (Wasilieva et al., 1985). The pattern of antibody distribution was determined among the population studied. About $30 \%$ of the children and $85.7 \%$ of adults from 20 to 60 years old revealed antibody titre to influenza $C$ virus. In another study, serum samples from 193 individuals were investigated in parallel with HIT and ELISA. From 17 persons with increase of antibody titre to the virus, 8 were diagnosed with HIT and 9 with ELISA (Troisi and Monto, 1981).

Parainfluenza viruses form the next group of respiratory viruses characterized by haemagglutinating activity. Serological diagnosis was accomplished by means of HIT with guinea pig erythrocytes. Unspecific inhibitors from the serum and nasal washings were removed with RDE. Samples of serum and nasal washing from 237 individuals from 1 month to 74 years of age were investigated. The presence of antibody to three types of parainfluenza viruses was registered. Age-specific peculiarities of antibody distribution to parainfluenza viruses were revealed. It was shown that maximal concentration of antibodies to parainfluenza III virus is encountered among children of 2-5 years of age (Hrušková et al., 1981).

Accordingly, HIT is still being used as a micromodification which is simple and convenient; it enables the carrying out of investigations with a small quantity of specimen. The test is valuable in the serology of respiratory infections because it enables fine specificity evaluation of the aetiological agent.

The complement fixation test (CFT) is one of the traditional serological 
tests which is still used in applied virology. The comparative simplicity of the test and the possibility of group-specific reactions are the main advantages of CFT. The reaction is taken as a reference test in investigations where new serological techniques are used.

A conventional set of the techniques for serological diagnosis of influenza includes HIT and CFT. The sensitivity of CFT varies considerably and depends upon many different factors: age and immunological status of the investigated population, the type of viral antigen, and the kind of infection.

The minimal sensitivity of CFT was observed in an investigation of 302 paired sera from sick children (Hermsdorf, 1981). The diagnosis of influenza A infection was made, using CFT, only in $8 \%$ of cases as compared with $19 \%$ and $25 \%$ using the indirect haemagglutination test (IHT) and HIT, respectively. The difference between sensitivity coefficients of CFT and other tests (ELISA, HIT) appeared to be pronounced, but still it was lowest (19 out of 40) in a group of 40 patients investigated, as compared with 27 and 35 out of the same group for ELISA and HIT respectively (Hammond et al., 1980). Similar efficiency in influenza A diagnosis using HIT and CFT was observed in a group of patients during influenza H1N1 infection (Van Voris et al., 1985). Investigation of paired sera from 784 patients with acute respiratory diseases carried out by means of CFT and ELISA revealed similar diagnostic efficacy of both tests for influenza B infection and higher sensitivity of ELISA as compared with CFT for influenza A and parainfluenza infections (Julkunen et al., 1984).

The sensitivity of HIT was shown to be variable during the epidemic cycle, but efficacy of serological influenza diagnosis using CFT remained constant and approached $80 \%$. Efficacy of serological diagnosis of influenza using HIT varied during the epidemic cycle and was lowest in the inter-epidemic period $(\approx 30 \%)$; it increased considerably, up to $68 \%$, in the pre-epidemic period (a month before the start of the influenza epidemic in the city). After the end of the epidemic the sensitivity of HIT decreased to an inter-epidemic level (Taros, 1984). For this reason, the optimal combination for serological investigations of influenza should include CFT and HIT.

Serological diagnosis of adenoviral infection is usually based on CFT because of the circulation of many types of the viruses (more than 40). Comparison of adenoviral infections on paired sera from 20 patients revealed similar results, although antibody titre with ELISA was 100 times higher than with CFT (Roggendorf et al., 1982).

Diagnosis of respiratory-syncytial infection was made with CFT, using its micromodification. The test appeared to be equal in sensitivity to ELISA when 4 units and high-titred antigen were taken for the reaction (Heizmann and Gertw, 1982). High correlation in the results of CFT and ELISA was obtained in the investigation of 59 paired sera from infants and young children (Hu, 1983). The positive results were obtained in 22 infants and no rise was observed in 30 of the patients' sera. The correlation rate of these two 
methods was $88.1 \%$ but the antibody titre by ELISA was 300 times higher than by CFT.

Serological investigation of 183 persons with respiratory infections carried out by CFT and ELISA with antigen of Mycoplasma pneumoniae revealed the slightly higher sensitivity of CFT (95\%) compared with ELISA (92.2\%) on the basis of paired sera investigations from 98 patients. General correlation of both test results was $78-96.6 \%$ and depends upon serum dilution. The simplicity and reliability of ELISA as compared with CFT are emphasized (Fisher et al., 1986). The study was performed on 193 serum samples with Mycoplasma pneumoniae antigen in parallel in three tests (CFT, haemagglutination, immunofluorescence (IF) technique). The higher sensitivity of CFT was demonstrated in one of the groups (83\% of 59 patients) but the most valuable asset appeared to be the combination of HA and IF tests recommended for diagnosis of this infection (Rousseau and Tettmar, 1985). The study of 209 serum samples by means of CFT and ELISA with commercial Mycoplasma pneumoniae antigen showed that, while investigating recent infection cases, the results of both tests coincided. However, in $27 \%$ of cases where low antibody titre with CFT was observed, the samples appeared to be positive with ELISA; this can be explained by the higher sensitivity of the latter technique (Dussaix et al., 1983).

Therefore, CFT remains a very useful laboratory technique which provides group-specific diagnosis and still can compete with more recent tests in routine laboratory diagnostics.

Indirect agglutination reactions of various microorganisms are widely used for antibody determination in blood sera and other biological fluids of human and animal origin. Fixation of antigens on carriers (erythrocytes, or latex, coal or bentonite particles) results in a considerable increase in sensitivity of the agglutination reaction (Tilton, 1985). The important advantage of the indirect agglutination reaction is an easy method of reading the results without any complicated devices to determine antibody titre to respiratory viruses or their components. Erythrocytes and latex particles are most frequently used in serological work. Therefore, the results of indirect haemagglutination (IHA) and latex agglutination reactions for antibody determination to respiratory viruses are considerd in this part of the review.

The principle of IHA is based on application of erythrocytes sensitized with viral antigens which can easily be agglutinated with homologous antiviral antibody. The results of the reaction are read by formation of erythrocyte sediment in the plates' wells. According to sediment formation, the agglutination reaction is read in conventional units (from one to four pluses). A definitely positive sedimentation reaction is evaluated as two pluses and is considered as an end-point of titration. The test is somewhat subjective and the difference in results can vary 2-4-fold when read by different specialists. This disadvantage of the reaction is usually compensated by the parallel investigation of paired samples. 
IHA has been known for more than 40 years and many modifications have been introduced since then. They concern the kind of erythrocytes, and the method of their stabilization. The improvement of the test relates also to the choice of antigen, methods of antigen accumulation, purification and its fixation.

For sensitization of erythrocytes, natural and recombinant influenza viruses are used as well as some antigenic components of respiratory viruses: neuraminidase of influenza virus and hexon antigen of adenoviruses. No definite opinion has been formed as to the reagents which should be applied for antigen fixation to erythrocytes, except for IHA; as a classical reaction, the inhibition of IHA is being used for identification of viral agents (Black et al., 1983).

A modified IHA for determination of isotype anti-RS-virus antibody in sera and respiratory tract secretions has been proposed (Pokrovskaya et al., 1983). As compared with other techniques applied for antibody determination to respiratory viruses, IHA provides some definite advantages. Sensitivity of the reaction is similar to diagnostic tests of the third generation (enzyme- or radioimmunoassays) (Herrmann, 1982; Noskov, 1985). At the same time, it is evident that no special devices are needed to perform the reaction. Large scale production of lyophilized erythrocyte diagnostica can be initiated comparatively easily. It should be mentioned that these preparations have practically unlimited shelf-life even under tropical conditions. This enables standardization of the reaction conditions and makes the IHA method of choice, especially for poorly equipped laboratories or for work under field conditions (WHO, 1984). A minimal quantity of tested material is needed for IHA performance, which makes it possible to use blood taken by the finger-stick technique. Unspecific inhibitors in sera and in nasal washings exert no influence on the results of the test. No action of nonantibody substances in nasal secretions has been shown to affect the IHA results, although the substance neutralizes the biological activity of RS virus (Pokrovskaya and Leshchinskaya, 1982).

One of the main advantages of IHA is the short time needed for the test. Antibody to respiratory viruses can be determined within two hours after reception of the material in laboratory. It is important also that erythrocytes sensitized with viruses agglutinate antibody of isotypes $G, M$ and $A$, but it should be mentioned that IHA has some serious limitations for its application. Firstly, the reaction is quantitative and one needs some significant (four-fold) change in antibody titre of paired samples to judge whether there is the presence of antibody. Secondly, the specificity of IHA for antibody determination is lower than of HIT. Differentiation of antibody to influenza A viruses is demonstrated to be possible with IHA, between the subtypes of virus; it appears to be less distinctive for strain differentiation within subtype and does not exceed $1 / 5$ of the titre (Schefer et al., 1982). The specificity of IHA is even lower when applied for determination of antibody 
to parainfluenza viruses. Erythrocytes conjugated with parainfluenza 3 virus are shown to react with antibody to three types of parainfluenza viruses (Shchekanova et al., 1982).

The main stages of erythrocyte diagnostics preparation include collection of blood, preliminary treatment of erythrocytes, their stabilization, preparation of virus suspension, linking of virus to erythrocytes, determination of diagnostic quality of the preparation, and its conservation.

Sheep erythrocytes are most frequently used for diagnostic preparations owing to the possibility of taking large quantities of blood from an animal. The repeated taking of blood from one and the same animal allows standardization of erythrocytes for diagnostic preparation. Low sensitivity of these erythrocytes to viral haemagglutinins is also essential but some drawbacks regarding these erythrocytes should be mentioned: they contain Forssman antigen which induces agglutination of these erythrocytes with some serum samples up to a dilution of $1: 8$. There are two principal ways to eliminate unspecific agglutination of the sera. The first includes treatment of tested sera with stabilized erythrocyte suspension at $37^{\circ} \mathrm{C}$ for one hour. Application of stabilized erythrocyte suspension excludes the necessity for complement elimination from tested sera. Secondly, the minimal serum dilution can be increased up to $1: 16$, but this method can be recommended only for sera of adults in which antibody concentration is higher than in children's sera.

Sheep erythrocytes are easily agglutinated with nasal washings. Antibody concentration in nasal washings is considerably lower than in sera; therefore, adsorption of nasal washings with erythrocytes is an obligatory step for an investigation with IHA. Another drawback of diagnostic preparations made with sheep erythrocytes is their slow sedimentation rate, which can last up to $6 \mathrm{~h}$. No such disadvantage is inherent for preparations made with human erythrocytes ( $\mathrm{Rh}-$, I blood group). This kind of preparation is used for determination of minimal antibody concentrations to influenza $A(H 1 N 1)$ and $A(H 3 N 2)$ viruses produced in lymphoid cell cultures taken from tonsillar tissue. IHA sensitivity might be increased 100 times by taking plates with a greater volume of wells $(0.5)$. This is attained when the depth of the wells is increased by placing the additional plates with holes corresponding to the wells on the plate. In each well $0.4 \mathrm{ml}$ of tested material was placed and $0.025 \mathrm{ml}$ of $1 \%$ suspension of diagnostic preparation was added. No false-positive results were observed in this case (Ispolatova et al., 1983). In determination of antibody to rubella by means of IHA with human erythrocyte diagnostic preparation, reading of the results is possible in 15-30 min (Safford et al., 1985).

However, the first group of human erythrocytes is not readily available for mass production of diagnostic preparations. Therefore, use of turkey erythrocytes deserves serious consideration. Determination of antibody to tetanus reveals that the sensitivity of turkey erythrocyte preparations is 80 
times higher than the sensitivity obtained with sheep erythrocytes. An important advantage of this preparation is that the reaction proceeds at room temperature only for $40 \mathrm{~min}$ and no normal antibodies to turkey erythrocytes are present in human sera (Pitzurra et al., 1983). Similar data using turkey erythrocyte preparations are also obtained in influenza A and B antibody determinations. Erythrocytes of chickens, ducks and geese have been used previously for diagnostic preparations for IHA.

Preparations from native arythrocytes are unstable during storage. For this reason, erythrocytes are treated with formic, glutaraldehyde or acrylaldehyde before their sensitization with virus. The erythrocytes treated with these reagents retain their form, the antigenic characteristics of their membranes, and the ability to combine with viruses. The fixed erythrocytes become resistant to repeated freezing and thawing and can be kept up to one year at temperatures from +4 to $+6^{\circ} \mathrm{C}$ after removal of unfixed excess of aldehyde. After sensitization with viruses they can easily be lyophilized with stabilizer and restored in distilled water.

To obtain erythrocyte diagnostic preparations we mix $8 \%$ erythrocyte suspension and an equal volume of $3 \%$ formaldehyde at $37^{\circ} \mathrm{C}$ for $18 \mathrm{~h}$ with constant stirring. Fixation of erythrocytes with acrylaldehyde enables more sensitive preparations to be obtained (Konikova et al., 1981). Glutaraldehyde has been widely used for this purpose during the last few years (Cranage et al., 1983; Steinitz and Tamir, 1985).

Considerable improvement in this technology was achieved when erythrocyte treatment with tannic acid was proposed. Such treatment increases adsorption activity of erythrocytes to proteins. The same technique is relevant in regard to viral antigens (Konikova et al., 1981). In order to increase the sensitivity of preparations, conjugation of viruses with erythrocyte membranes, by means of covalent or ionic bonds, is applied. To couple influenza, parainfluenza and respiratory-syncytial viruses to erythrocytes, we use bisdiazotized benzidine. The reagent is synthesized from the basic benzidine and sodium nitrite at least once a month. It is stored at $-20^{\circ} \mathrm{C}$, distributed in small portions (Schwartzman et al., 1977; Shchekanova et al., 1982; Pokrovskaya et al., 1983). The coupling of native erythrocytes with different antigen using chromium (III) chloride is used frequently (Lengyel et al., 1985). The method is applicable for native erythrocytes or erythrocytes fixed initially with glutaraldehyde (Steinitz and Tamir, 1985). Preparations of this kind are easily stored for a month or more and initial fixation with glutaraldehyde prolongs shelf-life to 10 months. Additional advantages of this reagent are availability and stability. However, we failed to obtain reproducible results in our laboratory while coupling sheep glutaraldehyde treated erythrocytes with influenza viruses employing this coupling agent.

Isocyanate has been proposed recently for the coupling of proteins to erythrocytes. Preparations obtained with this technique are extremely 
sensitive because of high density of coupled antigens on the erythrocyte surface. At the same time they are highly specific (Drevin and Richter, 1985 ). For the same purpose, amydole solution is also proposed (Kuzmin et al. 1982). Nevertheless, the problem of choice of optimal coupling agent has not so far been solved and further research on such agents is still being pursued. The optimal relationship of these reaction components is determined empirically; the quantity of erythrocytes remains constant in such work. Virus concentration, for example of influenza virus, is to be determined anew only in the case of introduction of new influenza virus strains, which have not been used previously; the most variable part is the dose of coupling agent. Therefore, firstly, a preliminary test with increasing dosages of coupling agent is carried out and, only later, is the main batch of diagnostic preparation made with the optimal dose of coupling agent. Specificity and sensitivity of the test-kit should be determined. Erythrocytes sensitized with viruses are prone to spontaneous aggregation in buffered saline, and therefore special solvents with stabilization properties are used. More frequently, $1-2 \%$ rabbit serum devoid of antibody to erythrocytes and diluted with $0.85-1.5 \%$ stabilizing solution is applied for this purpose. In some cases the stabilization solvent from guinea pig serum appears to be optimal (Trofimova et al., 1985). The serum adsorbed with erythrocytes is convenient for lyophilization and should be diluted prior to testing.

The following controls are needed at all steps of diagnostic preparations: (1) there should be no unspecific agglutination of diagnostic preparation in the presence of stabilizing diluent; (2) no agglutination of native erythrocytes should occur under the action of minimal dilution of material tested; (3) sensitivity control of preparation against known diagnostic serum. The first and second of these controls are to be used in the routine procedure of antibody determination in sera and materials tested. The third control is needed only in the process of diagnostic production. Sensitivity of the preparation varies considerably and is dependent upon antigen concentration and dosage of coupling agent. Introduction into the control system of the known diagnostic serum enables standardization of the preparation sensitivity in the process of its production. Lyophilization of diagnostic preparations prolongs their shelf-life for several years irrespective of storage conditions or variations in ambient temperature or humidity. According to our experience, diagnostic preparation for influenza A virus antibody determination retains its activity for a year when stored even at $+37^{\circ} \mathrm{C}$. Irrespective of the stabilizing medium used for lyophilization, it is necessary constantly to stir erythrocytes with the medium before freezing. Vials with mixture are to be frozen immediately by placing them into ethyl alcohol at $-40^{\circ} \mathrm{C}$ in order to prevent stratification of the mixture. The main requirement for conserving medium is to ensure the immediate dissolution of erythrocytes out of the lyophilized condition and to conserve the initial activity of the diagnostic preparation, exerting no effect on the results of 
IHA. The specificity and activity of fluid should be controlled once a week and that of lyophilized preparations once a month with reference diagnostic sera. Reagent-tested material and $1 \%$ erythrocyte suspension are added in $25 \mu \mathrm{l}$ aliquots. The plates with reagent mixture are slightly tilted, kept for $40 \mathrm{~min}$ at $+37^{\circ} \mathrm{C}$ and later left at room temperature when the sensitized sheep erythrocytes are used. If the work is accomplished with human and turkey erythrocytes the plates are kept at room temperature. The reading of results is done when erythrocyte diagnostic preparation is sedimented in the control wells.

Antibody determination of influenza viruses in numerous serum and upper respiratory tract washing samples with IHA, IHT and CFT demonstrates the higher diagnostic efficiency of IHA as compared with other techniques. No special treatment of sera for the elimination of unspecific inhibitors and complement inactivation is needed for the IHA procedure (Schwartzman et al., 1977). The same technique is efficiently used for antiinfluenza antibody determination in serum samples from children (Hermsdorf, 1981) and for evaluation of serum and secretory antibodies to influenza B virus (Tzybulskaya et al., 1983).

The diagnostic efficiency of IHA can be increased considerably when immunological conversion is determined simultaneously in serum samples and nasal washings taken from the same person (Ispolatova et al., 1982). This approach seems to be especially promising for prophylactic efficacy of influenza vaccines. Influenza virus is known to have two surface glycoproteins, haemagglutinin and neuraminidase. Application of IHA enables separate determination of antibody to these antigens. There are two approaches: use of recombinant viruses which contain surface antigens of different origin from human and animal influenza viruses or isolation of viral antigenic component, its purification and its use for the sensitization of erythrocytes (Tamendarova et al., 1985).

Investigation of parainfluenza antibody reveals a high sensitivity of IHA which is 16-32 times greater than in IHT, but no intertypic differentiation of antibody within the group of parainfluenza viruses is possible in the reaction. Therefore, different kinds of antibody are revealed in IHA or IHT. Erythrocyte preparations sensitized with parainfluenza viruses induce no reaction with antibodies to both types of influenza, adenoviruses or RS-virus but more than half of the serum samples from children reconvalescent from parotitis provoked their agglutination (Shchekanova et al., 1982).

The sensitivity and specificity of IHA for determination of antibody to adenoviruses considerably exceeds corresponding data for diagnostic tests of the second generation (Mykhailova et al., 1986).

In a comparative investigation, the advantages of tannic acid versus chromium chloride were demonstrated in the study of antibody to adenoviral hexon antigen evaluation. The diagnostic preparation became more sensitive and less antigenic material was needed when the former 
reagent was used. Diagnostic preparations obtained with hexons of some advenoviruses exceeded in their sensitivity those from immunoenzymatic techniques (Lengyel et al., 1985).

IHA also appeared more sensitive for the determination of antibody to respiratory syncytial virus when compared with indirect immunofluorescent (IF) and neutralization tests (Leshchinskaya et al., 1985). Close correlation of the results of all these techniques was obtained when serum samples from both children and adults were investigated. Correlation of results of two tests (IHA and IF) was also observed when nasal washings were investigated. In order to determine antibody isotype each sample was placed in three rows on the plate. After reading of the results, the diagnostic preparation in the wells with negative results of IHA was washed and antibody to heavy chains of immunoglogulins $\mathrm{G}, \mathrm{M}$ or $\mathrm{A}$ was added to each row. A four-fold or greater increase of antibody titre in the material was considered as positive for antibody isotype (Pokrovskaya et al., 1983). A technological scheme for the production of erythrocyte diagnostic preparations for anti-RSV-antibody determination has been developed in the USSR (Trofimova et al., 1985).

Agglutination of latex particles has been known for three decades but it is not widely used for antibody determination to respiratory viruses although some attempts in this direction have been made. As a basis for the preparation of polysterol, latex particles of size $0.81 \mu \mathrm{m}$ were used (Tchaika and Gorbatchev, 1985). Soluble viral antigens are better adsorbed on the surface of latex particles. Sensitization of latex was carried out with nucleoprotein or matrix protein of influenza virus, which are common antigens within type $\mathrm{A}$ influenza viruses. For this reason, only type-specific diagnosis is possible with such preparations. Another approach to a diagnosis of influenza is connected with application of latex particles linked with fetuin. These sensitized particles agglutinate readily, being in contact with influenza viruses. Antibody-containing specimen was added to the working dose of virus determined in pilot experiments. After a long enough incubation for interaction of latex with antibody, latex particles sensitized with fetuin were placed into the wells. Antibody titre was evaluated according to the inhibition rate of latex particles (Aymard et al., 1982).

The reaction of radial haemolysis (RRH) is based on the ability of erythrocytes sensitized with virus to be lysed under the action of antibody in the presence of complement. For the sake of convenience the reaction proceeds in the agar medium. Sensitized erythrocytes and complement are mixed with melted agar; later, wells are cut into the solid agar layer into which tested material is placed. During incubation antibody diffuses into the agar layer and lyses the erythrocytes. Reading of the results is made by measuring the zone of haemolysis.

According to the conclusions of WHO experts no special instruments are needed for the performance of RRH, which enables determination of 
antibody titre in a single serum dilution (WHO, 1984). Unspecific inhibitors exert no influence on the reaction results; one can test serum using 5-10 $\mu$ l of a sample.

Nevertheless, some limitations of the reaction are known. Storage time of agar plates for the reaction is limited to several weeks only. One needs to adsorb a substantial amount of concentrated viral antigen with high titre on the erythrocyte. This increases the cost of plates intended for diagnostic purposes and impedes their dispatch to distant places. Besides this, it should be noted that only IgG isotype antibodies can be revealed by means of RRH. Isotype $M$ antibodies diffuse very poorly into the gel and isotype $A$ antibodies do not activate complement after reaction with the antigen. The latter fact precludes RRH application for the investigation of secretory immunity in acute respiratory infections.

RRH has been applied since 1975 and, since that time, some modifications of the test have been developed. Sheep erythrocytes are most frequently used in RRH although, for determination of antibody to neuraminidase of influenza A virus, optimal results are obtained with equine erythrocytes. Recombinant viruses are adsorbed to a greater extent onto these erythrocytes. The size and transparency of haemolysis zones are greater with equine erythrocytes than with erythrocytes of sheep and chicken (Grilli and Smith, 1983). In contrast to this guinea pig erythrocytes appear to be optimal for determination of parainfluenza viruses (Sadykhova, 1985). To increase sensitivity of the preparation it was proposed to treat erythrocytes with butanol for removal of lipids from surface membranes (Gibson et al., 1985). Preliminary treatment of haemagglutinating viruses (influenza) can be reduced by low speed centrifugation of virus containing allantoic fluid. There is some evidence that influenza viruses produced in tissue culture are more active in RRH when compared with viral antigens of allantoic origin (Yurkova, 1982). The relationship between erythrocyte and virus concentrations is determined empirically and varies considerably, ranging from $8 \%$ to $25 \%$ for erythrocytes and being in an even greater range for influenza virus (Yurkova, 1982; Grilli and Smith, 1983). Sensitivity of the preparation increases with the growth of virus concentration up to a certain level, then sensitivity remains constant when all erythrocyte receptors are saturated with influenza virus (Tchaika, 1985). Chromium (III) chloride $\left(\mathrm{CrCl}_{3}\right)$ has been used recently for diagnostic preparation made from haemagglutinating and nonhaemagglutinating viruses. Application of some other agents such as potassium periodate or carbodiimide has also been reported.

Conjugation conditions with $\mathrm{CrCl}_{3}$ depend on the kind of virus used. For example, one of the recommendations given is a $2.25 \mathrm{M}$ basic solution of $\mathrm{CrCl}_{3}$ diluted to 1:400. Equal volumes of $10 \%$ sheep erythrocyte suspension and influenza B virus suspension (10 $\mu \mathrm{g}$ of viral protein per millilitre) are mixed. One-half of the volume of freshly prepared $\mathrm{CrCl}_{3}$ solution is added 
and conjugation proceeds for $10 \mathrm{~min}$ at $4^{\circ} \mathrm{C}$ (Oxford et al., 1982). Conjugation of rhinoviruses to erythrocytes is carried out for $1 \mathrm{~h}$ at $37^{\circ} \mathrm{C}$ (Tchaika, 1985). According to a recently developed technique, protein $\mathrm{A}$ of Staphylococcus aureus was linked with $\mathrm{CrCl}_{3}$ to erythrocytes and adenovirus antigen was included in the agar gel. Antibody of the test material diffused into the gel, combined with protein A being concentrated on the surface of erythrocytes, and reacted with adenoviral antigen and complement (Fulton et al. 1984). A pool of guinea pig sera was used as a source of complement, its optimal solution being selected empirically; no correlation of complement activity between CFT and RRH was found (Yurkova, 1982). In some cases complement was placed on the surface of plates or dishes after the completion of the first step of the reaction when antibody diffused into gel and linked to erythrocytes (Fulton et al., 1984). The final concentration of erythrocytes ranged from $0.5 \%$ to $5.0 \%$, usually being $1.0-1.5 \%$. The final concentration of agarose depends on its brand and varied from $0.5-0.7 \%$.

The recommendations of various investigators on the regimen of RRH vary considerably. It has been recommended to prepare plates for RRH with $0.3 \mathrm{ml}$ of $10 \%$ erythrocyte suspension sensitized with influenza $\mathrm{B}$ virus by means of $\mathrm{CrCl}_{2}, 0.15 \mathrm{ml}$ of complement-guinea pig serum and $2.5 \mathrm{ml}$ of agarose gel. These plates can be stored at $4^{\circ} \mathrm{C}$ for several weeks. The procedure of plate incubation with tested sera and reading of results also seems to be quite different. Some authors incubate the plates for $18 \mathrm{~h}$ at $4^{\circ} \mathrm{C}$ or for $3 \mathrm{~h}$ at $37^{\circ} \mathrm{C}$ (Demidova, 1980), others for $18 \mathrm{~h}$ at $37^{\circ} \mathrm{C}$ and then read the results at $4 \mathrm{~h}$ and $18 \mathrm{~h}$ (Oxford et al., 1982). The first regimen of incubation is appropriate for native erythrocytes and the second for erythrocytes treated with chromium.

High reproducibility of RRH has been reported; no false-positive results were observed in the diagnosis of influenza. A haemolysis zone of $2 \mathrm{~mm}$ was considered as a positive result for RRH. A clear general correlation of positive results for RRH and HIT was observed but some variation of the haemolysis zone from 2.0 to $4.6 \mathrm{~mm}$ for the serum with $\mathrm{HI}$ titre $1: 32$ was registered whereas serum sample with $H I$ titre 1:256 gave a diameter of 4-8 $\mathrm{mm}$ in the RRH zone (Demidova, 1980). A strong correlation for RRH and HIT results (correlation coefficient 0.83 ) was obtained by other authors. The protective level of antibody to influenza was shown to be $43.4 \mathrm{~mm}^{2}$ in an experimental infection of volunteers (Goodeve et al., 1983). The comparative sensitivity of these tests in influenza diagnostic investigations is considered to be equivocal. Sometimes the higher sensitivity of HIT is accounted for by the influence of unspecific serum inhibitors (Pettersson, 1980). The sensitivity of RRH can be influenced by the peculiarities of the virus used for the reaction, and RRH appears to be more sensitive when influenza strains with low avidity are applied (Aymard et al., 1980). The sensitivity of RRH exceeds the sensitivity of HIT in determination of antibody titre to influenza $A$ virus $A / B r a s i l / 11 / 79$ (Mancini 
et al., 1983). Noteworthy results were obtained in the study of antibody determination to the neuraminidase of influenza A virus. It became evident that the dose of recombinant virus taken for the reaction in this case depended on the characteristic of haemagglutinin in the recombinant. In a comparative study of MRC-3 and X-38 strains for RRH the latter virus appeared to be more appropriate. Strong correlation of antineuraminidase antibody titre was found between the results of RRH and other conventional techniques (Callow and Beare, 1980). Investigation of monoclonal antibody with RRH confirmed the diagnostic efficacy of the reaction. Introduction of monoclonal antibody to neuraminidase of influenza virus resulted in the appearance of a clear haemolysis zone even when the erythrocytes were sensitized with both surface antigens of human influenza virus. Therefore, with use of whole influenza viruses of human origin in RRH, antibody activity to both antigens was evaluated simultaneously (Grilli and Smith, 1983). Recently, RRH was used for the determination of antineuraminidase antibody in the sera of ponies (Gibson et al., 1985). Some investigators used RRH erythrocytes sensitized with different variants of influenza $B$ virus and evaluated immunological activity during reinfection (Grilli and Davies, 1981). RRH was also successfully applied for antibody determination to parainfluenza virus (Sadykhova, 1985), adenovirus (Fulton et al., 1984) and respiratory syncytial virus (Yurkova et al., 1983).

\section{RECENT TESTS}

The enzyme-linked immunosorbent assay (ELISA) is attaining widespread use for the detection both of antibody and of antigens in biological material. The principle of the reaction appears to be extremely promising and is widely used in laboratory routine. The test is easy to perform and it enables objective reading of results. A very important stage of the assay is adsorption of antigen to experimental plates. The process of adsorption and desorption was investigated in detail using BSA as an antigen (Nieto et al., 1986). It was shown that the process of adsorption follows the Langmuir isotherm with a constant of adsorption equal to $2.1 \times 10^{8} \mathrm{I} / \mathrm{mol}$ and maximal surface concentration of protein $1.8 \times 10^{-7} \mathrm{~g} / \mathrm{cm}^{2}$. Although desorption was present, it had no effect on the results of ELISA. Enzymatic activity of the conjugate on heterogeneic immunoassay analysis was shown to be independent of its participation in the immune reaction. In contrast to this, conjugate activity in homogeneic analysis changed in the process of the immune reaction (Voller and Bidwell, 1985).

One of the important steps of ELISA is preparation of enzyme-labelled immunoglobulin. Usually, horseradish peroxidase is coupled with immunoglobulin at $\mathrm{pH} 6.8$ in the presence of 0.05 proc glutaraldehyde solution, 
but it is well known that only $1 \%$ of enzyme is coupled with immunoglobulin during the classical procedure of peroxidase labelling.

A method has been established purporting to increase the labelled immunoglobulin activity 10-20-fold. The method concerns the labelling of immunoglobulin in two steps. In the first step, the reaction proceeded at a lower $\mathrm{pH}$ of 5.7 , which enabled the better solubilization of enzyme. The second step was accomplished after dialysis against phosphate buffer $(0.01 \mathrm{M}, \mathrm{pH}$ 7.2) containing several salts. The second step of the reaction proceeded with the addition of glutaraldehyde at a final concentration of $0.25 \%$. As a result of this procedure about $10-15 \%$ of the enzyme was connected with immunoglobulin (Yankina et al., 1984).

Recently, some other methods for the development of ELISA have been proposed, for example the biotin-avidin technique, which is based on high affinity of avidin to biotin. Each avidin molecule can bind four molecules of biotin which can be covalently coupled to antibody of high specific activity without affecting their antigen-binding capacity. Application of a developed ELISA with the biotin-avidin system has been described for quantitation of human $\operatorname{IgA}$. The sensitivity of the test increased to $1 \mathrm{ng}$ of $\operatorname{IgA}$ in a $50 \mu \mathrm{l}$ of sample $(20 \mathrm{ng} / \mathrm{ml})$ (Adler-Storthz et al., 1985). Further simplication of an indirect ELISA was described when the conjugate of Staphylococcus protein $\mathrm{A}$ with horseradish peroxidase was used to reveal the antibody titre to influenza in serum samples. Sensitization of plates was accomplished with the whole virus or haemagglutinin of influenza A virus. The modification of ELISA provides a reliable technique of antibody determination. Application of whole virus versus haemagglutinin for sensitization gave somewhat broader results. Sensitivity of immunoenzymatic reaction was higher than that of HIT: of 17 serum samples negative to HIT, 7 appeared to be positive to ELISA (Egorenkova et al., 1987).

Sensitization of plates for ELISA is also important for final results. In most cases, purified virus is taken for sensitization. The optimal concentration of influenza $A$ virus used for the purpose was found to be $10^{3} \mathrm{HAU} / \mathrm{ml}$ (Babikova et al., 1984; Kozhukhov et al., 1985). The lower concentration of antigen $\left(10^{2} \mathrm{HAU}\right)$ was also described for avian influenza viruses (Abraham et al., 1986). Approximately the same concentration of influenza antigen $(100 \mathrm{HAU} / \mathrm{ml})$ was used in a study with influenza A (H1N1) virus (Hammond et al., 1980).

The recommended incubation time for an antigen is $4 \mathrm{~h}$ at $4^{\circ} \mathrm{C}, \mathrm{pH} 7.4$, although virus adsorbed during the night has also been used (Schmidt $e t$ al., 1984). Carbonate buffer at $\mathrm{pH} 9.8$ gives less favourable results for antigen adsorption (Babikova et al., 1984).

Incubation of plates with tested sera at $37^{\circ} \mathrm{C}$ in the second step usually lasts for $2 \mathrm{~h}$ but when IgM antibody is evaluated prolonged incubation of the plates lasting for $18-48 \mathrm{~h}$ at $4^{\circ} \mathrm{C}$ is recommended. Short incubation periods in such cases result in lowered sensitivity and specificity of the test (Rosmus 
et al., 1985). Sensitized plates can be kept for $4-5$ days at $4^{\circ} \mathrm{C}$ without loss of activity. Storage at $-20^{\circ} \mathrm{C}$ is less favourable.

ELISA is widely used both for diagnostic purposes and for evaluation of immune response in those vaccinated. In all the investigations dealing with vaccination it was shown that antibody titre with ELISA is 10-60 times higher than in conventional tests (Jennings et al., 1981; Schmidt et al., 1984; Kozhukhov et al., 1985). However, the number of individuals with seroconversion appeared to be even lower than that observed with HIT although even two-fold rises were considered as positive for ELISA. In total 58 of 74 volunteers showed four-fold rises when tested by HIT while 21 of 44 volunteers demonstrated two-fold rises with ELISA (Jennings et al., 1981). There was general agreement of the enzyme immunoassay results with HIT in all the investigations, although with influenza A (H1N1) viruses this agreement was not so pronounced (Schmidt et al., 1984).

The sensitivity of ELISA in diagnosis of influenza varies but the results are usually higher than in conventional tests (CFT, HIT, NT) (Van Voris et al., 1985; Lange and Masihi, 1980; Julkunen et al., 1985). Evidence has been presented that ELISA demonstrates lower sensitivity than HIT, giving 27 and 35 positive cases respectively out of 40 persons investigated (Hammond et al., 1980).

A serious drawback of ELISA as applied for influenza A virus diagnosis is that it provides only type-specific diagnosis when whole virus is used for plates' sensitization. In spite of using purified haemagglutinin from influenza A H1 and $\mathrm{H} 3$ subtypes in ELISA, HIT still remains the serological method of choice for determining the causative subtype of influenza A virus infection (Julkunen et al., 1985). These findings were obtained during an investigation of 455 patients with acute respiratory infection. It was shown that ELISA was a more important test which confirmed the diagnosis of a greater number of influenza A or B cases compared with CFT or HIT. Therefore, ELISA is a very useful test as it provides class-specific determination of antiviral antibody. Moreover, evaluation of antibody isotype with ELISA can specify the immune protection (Julkunen et al., 1985; Murphy et al., 1981).

Serological diagnosis of influenza B or C infections by means of ELISA is more appropriate because no further determination of subtype specificity is needed for these infections. Parallel investigations of 784 patients with acute respiratory diseases by means of ELISA and CFT produced similar results of influenza B diagnosis in both tests: 104 and 99 cases respectively (Julkunen $e t$ al., 1984). However, ELISA appeared to be more sensitive in another study in which 27 persons were investigated. The increase in geometric mean titre with ELISA was 16-71-fold as compared with 3-10-fold for HIT (Turner $e t$ al., 1982). In both investigations high reliability and sensitivity of ELISA for determination of antibody to influenza B were demonstrated.

As for influenza $C$ infection, the investigation of serum samples from 193 
individuals by means of ELISA revealed 16 positive results (Troisi and Monto, 1981). The most striking result of this study was the strain specificity of the diagnostic results, because only 5 samples appeared to be positive with both strains used, 8 samples with influenza strain C/New Jersey/1/76, and 3 samples with strain C/Ann Arbor/1/59.

Diagnosis of adenoviral infections with ELISA seems to be a convenient and easy technique because determination of hexon antigen of adenoviruses enables one to diagnose the whole group of adenoviral infections. Early diagnosis of ophthalmic adenoviral lesions is of importance for urgent therapy. For example, ELISA was used for the investigation of conjunctivitis samples from 100 patients. IgA antibodies to adenoviral hexon antigen were determined in $53 \%$ of cases; a combination of this result together with detection of hexon antigen increased the number of cases diagnosed to $69 \%$. IgA antibody was revealed within the first 7 days of infection (Kühn et al., 1984). Increased sensitivity of ELISA enabled usage of serum in a dilution as high as $10^{-3}$ (Roggendorf et al., 1982).

Increased sensitivity of ELISA resulted in unfavourable reactions which became evident in the diagnosis of parainfluenza infections. Comparison of ELISA and CFT for serological diagnosis of parainfluenza demonstrated the higher sensitivity of the former test, because the number of those diagnosed was equal to 47 cases with ELISA and 30 cases with CFT out of 180 persons investigated (Julkunen, 1984). Application of purified surface gP or nucleocapsid antigens resulted in determination of cross-reactions between parainfluenza 1 and 3 and parotitis viruses. Cross-reactions between the same viruses are also revealed in other work. Examination of 213 serum samples by ELISA demonstrated 30-50-fold higher rises of antibody titre to parainfluenza than by CFT. The lowest correlation of ELISA results was found for parainfluenza 1 virus. Cross-reactions between parainfluenza 1, 3 and parotitis viruses were shown in $25 \%$ of cases (Kessler et al., 1982).

Respiratory syncytial virus is one of the predominant pathogens affecting small children. ELISA has been efficiently used for serological confirmation of the infection's diagnosis. The test appears to have been especially useful in an investigation of serum samples from 80 children when antibody titre using ELISA was found to be 10-15 times higher than with CFT (Bračková et al., 1981). Mikuni (1982) came to the same conclusion when investigating 106 serum samples including 35 paired sera tested in parallel with ELISA, CFT and passive haemagglutination. The number of positive serological findings among infants (1-3 months of age) were considerably higher with ELISA than with CFT. However, quite different results were shown when basing an investigation on 59 paired sera from infants and young children. Close correlation of ELISA and CFT results was obtained and the number diagnosed serologically by means of ELISA was equal to the number diagnosed with CFT (Hu, 1983).

Serious difficulties are encountered with ELISA when low dilutions of 
serum or secretion are tested for IgA antibody determination. Residual nonspecific binding of IgA in these materials is probably due to lipids or lipoproteins of an antigen. As was demonstrated, the unspecific binding was markedly reduced by additional treatment of the infected cell treated with arklone. Using this modified ELISA technique for anti-RS virus IgA a good correlation was found with unfixed cell membrane immunofluorescent data (Nandapalan et al., 1984).

A simplified ELISA procedure was proposed to assess antibody titre to RS virus in sera from hospitalized children. Modification of the test consisted of the use of infected cells for sensitization of plates. The plates could be stored, ready for use, at $4^{\circ} \mathrm{C}$ for at least 3 months. Approximately 5000 cells per well appeared to be optimal for the test. The efficiency of the new ELISA modification and of CFT were compared while testing 96 serum samples. Immunoenzymatic analysis was more sensitive than the conventional test: eight sera determined as negative by CFT were found to be positive by ELISA. The latter test was also more convenient because one only needs a single serum dilution for testing (Vaur et al., 1986). Coronaviral infections are provoked by at least four distinct serotypes of the virus. ELISA revealed group-specific antibodies but no identification of virus serotype was possible with the test, in contrast to the neutralization test (NT). However, antibody titres in ELISA were found to be higher than with NT (Marquardt et al., 1981). Determination of antibody to coronaviruses with ELISA is accomplished with two strains: 229E4 and OC-43. Investigation of 298 sequential serum samples taken from 37 adults over a period of 5 years demonstrated the seasonal variations of coronavirus infections. ELISA seemed to be perfectly suited for this purpose (Macnaughton, 1982).

Mycoplasma pneumoniae is an important respiratory pathogen, especially among adults under some specific conditions. Sonicated lyophilized antigen in a concentration of $0.14 \mathrm{mg}$ of protein per millilitre was used for coating plates (Jacobs et al., 1986). Parallel investigations of 183 serum samples by means of ELISA and CFT demonstrated a similar level of sensitivity equal to 95\% for CFT and $92.2 \%$ for ELISA. Correlation of the results of both tests was higher and depended on the dilution of sera tested. It appears that CFT is somewhat more sensitive than ELISA but the latter test is more reproducible and simple (Fisher et al., 1986). Detailed comparison of these tests revealed some age-specific peculiarities in the diagnosis. Based on the results of an investigation of 209 serum samples, it was shown that new cases of infection were diagnosed with similar efficiency by CFT and ELISA but low CF titres were revealed with greater reliability by ELISA. The number of cases alone diagnosed by ELISA was $27 \%$ of the samples tested, which can be explained by the higher sensitivity of ELISA. One of the advantages of ELISA is the possibility of determining class-specific antibodies to the infectious agent (Dussaix et al., 1983).

Therefore, ELISA is a convenient and simple technique for serological 
diagnosis of respiratory infections; it enables determination of class-specific antibodies to respiratory pathogens. Usually, it gives higher antibody titre than conventional tests but this cannot always be regarded as an advantage because a number of seroconversions may be the same or even lower when vaccinated persons are investigated. Generally, group-specific antibodies are revealed in the test and special technical modifications are required to make subtype-specific diagnosis possible.

The immunofluorescent (IF) staining technique is still used in serological investigations with respiratory pathogens. The advantages are sensitivity and the possibility of class-specific antibody evaluation. The IF technique is widely used for rapid diagnosis in pediatric clinics. Because RS infection is predominantly a respiratory pathogen in infants, the technique is also applied extensively for serological investigation. Comparison of this test with other techniques for serological investigation of respiratory syncytial infection was carried out on 47 serum samples obtained sequentially from infants and young children with RS infection. IgG, IgM, IgA antiviral antibodies were determined by means of indirect immunofluorescent assay on slides with cells infected with RS virus. The results obtained in the test correlated with the data of other techniques (NT and its modification). Antibodies to RS virus were detected by three techniques as early as 4 days after the onset of illness. Although the titre in IF apppeared to be somewhat lower than in the other tests, the IF assay was more rapid and less laborious than NT (Kaul et al., 1981). Moreover, IF assay can be used for the detection of RSV-IgM antibody and may therefore be useful in the early serological diagnosis of RS infection.

IF was also applied in broad sero-epidemiological investigations. Serum samples from populations of two African countries were investigated for the determination of antibody to RS virus. The data obtained revealed epidemiological peculiarities of the infection as dependent on geographical conditions (Achong and Epstein, 1983).

In the other serological study, sera from 85 children with acute respiratory diseases were investigated. This test was used on the model of MDCK, HeLa and Hep-2 cells infected with respiratory viruses, for determination of IgM or IgG antibodies to main respiratory pathogens of viral origin. Of 52 patients with mixed infections (influenza + adenoviral infection or influenza + RS infection) the diagnosis of influenza was confirmed in 21 and 12 patients respectively. Antibodies of the IgM class were revealed 3-4 days after the onset of uncomplicated infection and 5-6 days in cases with complications. The presence of IgM antibodies persisted for 3-15 days. Of 30 patients with mixed infection, IgM antibodies to both viruses were demonstrated in 10 . The other patients were recent reconvalescents of adeno- or RS infections (Iwanova et al., 1986).

The new modification of the immunofluorescent technique consists of investigating unfixed infected cells or evaluating membrane immuno- 
fluorescence which gives results closer to the titre of virus neutralizing antibodies. Application of this technique provided good correlation with the modified ELISA for investigation of nasal washings and human colostrum samples (Nandapalan et al., 1984).

The suitability of the IF test depends largely on simple and available test objects which can be used in serological investigation. Human erythrocytes coupled with influenza viruses were used for serological diagnosis in an indirect immunofluorescent test. Out of 73 serum samples, IgM antibody to influenza virus was revealed in $24.7 \%$ with IFT and in $23.3 \%$ with CFT and HIT. The technique was appropriate for early serological diagnosis of influenza within 4 days (Zhurov and Waserin, 1985) and was applied in other work (Döller et al., 1985). The biotinylated system has been used to reveal class-specific antibody. As a result of an IF investigation of sera from 76 patients with confirmed influenza, it was shown that only $27.6 \%$ of samples contained antibodies of all Ig classes: $51 \%$ of the sera contained IgG and IgA antibodies, and $3.9 \%$ of patients responded with $\mathrm{IgG}$ isotype. Evidence demonstrated an influenza infection as having high titre of IgG or lower titre of IgG combined with moderate IgM antibody titre (Döller et al., 1986). The advantage of the IF test is related to subtype specificity of the results obtained as compared with ELISA.

The haemadsorption immunosorbent (HI) test is an interesting combination of the immunosorbent assay and indirect haemadsorption technique. For this reason a more simple system for reading of the results is required than for the immunoenzymatic assay. The first modification of the test was reported to have been for IgM antiviral antibody determination. The wells of the plate were sensitized with antibody to M-chains of human IgM, and serum dilutions and $1 \mathrm{AU}$ of parainfluenza virus were placed into the wells and incubated for one night. Then $0.1 \mathrm{ml}$ of $0.07 \%$ guinea pig erythrocyte suspension was put into the wells and the results were read. The titre of antibody to parainfluenza virus ranged from $1 / 160$ to $1 / 80000$ and they were revealed in 26 out of 29 persons investigated (Van der Logt et al. , 1982). The same authors investigated paired sera from 763 patients with acute respiratory diseases to evaluate $\operatorname{IgM}$ antibodies to parainfluenza infection. Evidence of this infection was found in 122 patients $(16 \%)$. The haemadsorption immunosorbent test appeared to be superior to HIT for the detection of parainfluenza infections. In particular, while investigating the serum of infants and aged patients, 94 samples were shown to be positive only when the haemadsorption immunosorbent test was used, 12 were estimated with HIT, and 16 with both reactions. IgM parainfluenza antibodies persisted for 2-11 weeks after the onset of infection (Van der Logt et al., 1985). Application of the same technique by another group of authors for determination of IgM antibodies to parainfluenza and mumps viruses revealed a twofold higher level of sensitivity in the immune haemadsorption test than with CFT (Roussel et al., 1984). 
The same test can also be applied for antibody determination to viruses without haemagglutinating activity. The reading of results in this case proceeds with erythrocytes chemically bound to corresponding viral antigen. This work was carried out with respiratory syncytial virus. The wells of plates were sensitized with RS antigens obtained from HeLa cells. After incubation and washings, tested serum samples were placed into the wells and $1 \%$ suspension of erythrocytes bound with RS virus was added. The reading of the results occurred within $90 \mathrm{~min}$. Close correlation of results of the test with the data of other tests was found (ELISA, CFT, IFT) (Cranage and Coombs, 1982). Investigation of 106 serum samples with the haemadsorption immunosorbent test, ELISA and CFT revealed higher sensitivity of ELISA over the haemadsorption immunosorbent test when sera from infants of 1-3 months of age were investigated, but in some infants the results obtained with $\mathrm{HI}$ appeared quite comparable with those of other conventional serological techniques (Mikuni, 1982).

The immunoblotting test is performed with patients' sera against the antigen run on nitrocellulose paper. If the antigen is placed on the nitrocellulose sheet and no electrophoresis is performed, the antibody level is estimated against whole antigen. After the antigen is placed on the nitrocellulose and dried for $0.5 \mathrm{~h}$ at room temperature, the sheets are incubated for $2 \mathrm{~h}$ in $5 \%$ or $10 \%$ skimmed milk to saturate nonspecific binding sites. Each strip of paper is overlaid with $1 \mathrm{ml}$ of human serum diluted 1:100 and, after successive washings, antihuman immunoglobulins labelled with enzyme are placed on the sheets. The further treatment of sheets depends on the enzyme used. Horseradish peroxidase is developed with $3^{\prime}, 3^{\prime}$-diaminobenzidine or 4-chloro-1-naphthol.

The electrophoresis of complex antigen enables antibody determination to antigenic components of the pathogen. Investigations of this kind were performed with human sera against mycoplasma pneumonia antigen (Jacobs et al., 1986). Age-specific peculiarities were revealed in the study. It was shown, for example, that antibody to $168 \mathrm{kD}$ protein is very rarely encountered in the sera of children up to 7 years, but in senior age-groups a considerable number of reactions with proteins of 193, 168, 84, 69 and $56 \mathrm{kD}$ are detected. After several months the IgG pattern in most cases again includes a persistent antibody level against the $168 \mathrm{kD}$ protein. It seems, however, that the antibodies remaining after a longer interval do not protect the individual. Better-characterized antigens used for the primary test would prove more reliable than the crude antigens used so far. Immunoblotting analysis can provide such detailed immunological characterization.

\section{CONCLUSION}

The set of techniques now applied for serological diagnosis of respiratory 
infections varies considerably. The techniques used are of different specificity, sensitivity, reliability; they vary also in their ability to determine immunoglobulins of various isotypes, and in their sensitivity to unspecific inhibitors. Only some of the techniques can be regarded as quantitative. Most of them are based on evaluation of antibody in two-fold dilutions of material tested. Stability and shelf-life duration of preparations or necessity for complicated devices are also of importance in the comparative characteristics of serological techniques.

For serodiagnosis of respiratory infections well-equipped laboratories can apply the immunoenzymatic test (ELISA) which is of high sensitivity but provides most frequently group- or type-specific diagnosis. Sedimental reactions of indirect immunological analysis are especially convenient in field conditions when the standardized diagnostic preparations are available and these methods provide exact aetiological characteristic of infection.

Conventional techniques such as HIT or CFT still remain valuable because, by means of HIT, it is possible to obtain strain-specific differentiation of antibody. CFT is a simple and reliable test for group-specific diagnosis. Together, these two techniques are still valuable in seroepidemiological surveillance of influenza in the USSR.

RRH is a convenient reaction because there is no need to dilute the serum tested. This makes the test very appropriate for mass seroepidemiological trials and to obtain qualitative results although it is still difficult to obtain reproducible data with some antigens.

The immunofluorescent technique as well as ELISA enable determination of antibody isotype but one needs some complicated devices, reliable test material and highly qualified personnel to work with. Nevertheless, the techniques are promising in aetiological investigations of mixed infections.

The haemadsorption immunosorbent test seems to be very promising because it combines the simplicity of ELISA and ease in reading of results attributed to haemadsorption techniques. Possible applications of this test need further investigation.

One of the advantages of the immunoblotting technique is the possibility of an immunological answer to single antigenic components of complex antigens; it is also known that the majority of respiratory antigens are enveloped viruses and that they have complex antigenic structures.

Unfortunately, not all hopes for the development of rapid serological diagnosis in seroepidemiology come true (WHO, 1984; Richman et al., 1984). Nevertheless, retrospective serological diagnostic tests are still required in infectious diseases and take on considerable importance in the work of hospital laboratories. Laboratory confirmation is required, both for clinicians, to sharpen their clinical judgement, and for patients, in order to guide them correctly.

It goes without saying that all the tasks enumerated cannot be solved by means of one technique of antibody determination. In our opinion, in 
serodiagnosis of each respiratory infection, one should determine an optimal set of techniques which provide sufficient and essential diagnostic information.

\section{REFERENCES}

Abraham, A., Sivanandan, V., Halvorson, P. A. and Newman, J. A. (1986). Standardization of enzyme-linked immunosorbent assay for avian influenza virus antibodies in turkeys. Amer. J. Vet. Res., 47, 561-566.

Achong, B. G. and Epstein, M. A. (1983). Naturally occurring antibodies to the human syncytial virus in West Africa. J. Med. Virol., 11, 53-57.

Adler-Storthz, K., Dreesman, G. R., Graham, D. J. and Evans, D. G. (1985). Biotin-avidin amplified ELISA for quantitation of human IgA. J. Immunoassay, 6, 67-77.

Aymard, M., Million, J. and Kessler, N. (1980). Diagnostic sérologique rapide de la grippe par la méthode d'hémolyse radiale modifiée et évolution des anticorps. Pathol. Biol., 28, 535-539.

Aymard, M. , Quasb, G. and Million, J. (1982). Determination of antineuraminidase antibody titers in human sera by inhibition of the agglutination of fetuin-latex by influenza viruses. J. Biol. Stand., 10, 125-133.

Babikova, N. W., Schustova, N. D., Waserin, Yu, J., Bliznyuk, V. V., Kobyakova, T. N., Dzantiev, B. B. and Egorov, A. M. (1984). Enzyme immunoanalysis. Conditions for quantitative determination of antibody to influenza virus. Vopr. Med. Khim., 4, 17-20 (in Russian).

Black, S. B., Raas, M., Mintz, L., Shinefield, H. R. and Drew, W. L. (1983). Indirect hemagglutination inhibition: a direct method for detecting cytomegalovirus antigen. J. Lab. Clin. Med., 101, 450-452.

Bračková, M., Švandová, E. and Syrůcek, L. (1981). Detection of respiratory syncytial virus serum antibodies by an ELISA system. Acta Virol., 25, 41-48.

Callow, K. A. and Beare, A. S. (1980). A re-examination of single radial haemolysis technique for the assay of influenza anti-neuraminidase antibodies in human sera. Arch. Virol., 65, 25-35.

Celedón, M., Berrios, P., Ibarra, L., Pinto, M. and Ramirez, S. (1982). Inhibicion de la hemaglutinacion: comparacion de macro y micrometodo (virus de la enfermedad de Newcastle e enfluenza equina). Zentralbl. Veterinärmed., 29, 5-56.

Chakraverty, P. (1980). Comparison of haemagglutination-inhibition and singleradial-haemolysis techniques for detection of antibodies to influenza $\mathrm{B}$ virus. Arch. Virol., 63, 285-289.

Cranage, M. P. and Coombs, R. R. A. (1982). An indirect haemadsorption procedure $\left(\mathrm{M}_{\mathrm{RS}} \mathrm{PAH}\right)$ for detecting antibodies to respiratory syncytial virus. $J$. Virol. Methods, 5, 199-208.

Cranage, M. P., Gurner, B. W. and Coombs, R. R. A. (1983). Glutaraldehyde stabilization of antibody-linked erythrocytes for use in reverse passive and related haemagglutination assays. J. Immunol. Methods, 64, 7-16.

Demidova, S. A. (1980). Radial haemolysis test for determination of antiinfluenza antibodies in human sera. Vopr. Virusol., 6, 731-735 (in Russian).

Döller, G., Döller, P. C. and Gerth, H.-J. (1986). Diagnostic significance of influenza subtype-specific $\operatorname{IgG}, \operatorname{IgA}$, and IgM antibodies. J. Biol. Standard., 14, 163-175. 
Döller, P. C., Döller, G. and Gerth, H.-J. (1985). Immunofluorescence test with antigen-loaded erythrocytes: detection of influenza virus specific $\operatorname{IgG}, \operatorname{IgA}$, and IgM antibodies. Med. Microbiol. Immunol., 173, 291-302.

Drevin, H. and Richter, W. (1985). Covalent coupling to erythrocytes by isozianide. A new sensitive and mild technique for identification and estimation of antibodies by passive hemagglutination. J. Immunol. Methods, 77, 9-14.

Dussaix, E., Slim, A. and Tournier, P. (1983). Comparison of enzyme-linked immunosorbent assay (ELISA) and complement fixation test for detection of Mycoplasma pneumoniae antibodies. J. Clin. Pathol., 36, 228-232.

Egorenkova, E. M., Khristova, M. L., Leonova, S. V., Kozhukharova, M., Demidova, S. A. and Kharitonenkov, I. G. (1987). Use of enzyme-immunoassay with Staphylococcus protein A/peroxidase conjugate in serodiagnosis of influenza. Vopr. Virusol., 32, 168-172 (in Russian).

Fattal-German, M., German, A. and Fattal, S. (1980). Titrage des anticorps sériques antigrippaux par l'hemagglutination: intérêt de l'emploi d'antigens non sensibles aux inhibiteurs non spécifiques. Ann. Pharm. Fr., 38, 27-33.

Fisher, G. S., Sweimler, W. J. and Kleger, B. (1986). Comparison of Mycoplasmelisa with complement fixation test for measurement of antibodies to Mycoplasma pneumoniae. Diagn. Microbiol. Infect. Dis., 4, 139-145.

Fulton, R. E., DiNinno, V. L., Frank, R. J., Fildes, V. and Turner, J. S. (1984). Single radial haemolysis test for quantitation of complement-fixing antibodies to non-haemagglutinating viruses. J. Clin. Microbiol., 20, 248-254.

Gibson, C. A., Wood, J. M., Mumford, J., Schild, G. C. and Bevan, A. M. (1985). A single-radial haemolysis technique for measurement of antibody to influenza virus neuraminidase in equine sera. J. Virol. Methods, 11, 299-308.

Goodeve, A. C., Jennings, R. and Potter, C. W. (1983). The use of the single radial haemolysis test for assessing antibody response and protective antibody levels in an influenza B vaccine study. J. Biol. Standards, 11, 288-296.

Grilli, E. A. and Davies, J. R. (1981). Influenza B at Christ's Hospital: natural antibody to influenza B estimated by radial haemolysis. J. Hyg., 87, 211-218.

Grilli, E. A. and Smith, A. J. (1983). The use of a radial haemolysis test for neuraminidase in the diagnosis of influenza A infection. J. Hyg., 91, 147-156.

Hammond, C., Smith, S. J. and Noble, C. R. (1980). Sensitivity and specificity for serodiagnosis of influenza A virus infections. J. Infect. Dis., 141, 644-651.

Heizmann, W. and Gertw, H.-J. (1982). Comparison of an enzyme immunoassay with complement fixation test for detection of $\mathrm{IgG}$-antibodies against respiratory syncytial virus. Zentralbl. Bakteriol. Parasitenkd. Infektionskr. Hyg., 253, 18.

Hermsdorf, St. (1981). Vergleichende Untersuchungen über den Wert der passiven Hämagglutination, der Komplementbindungsreaktion und des Hämagglutinationshemmungstests zur Erfassung von Influenzaviruserkrankungen bei Kindern. Z. Gesamte Hyg. Grenzgeb, , 29, 616-618.

Herrmann, K. (1982). Newer development in rapid viral-disease diagnosis. Lab. Manag., 20, 63-69.

Hrušková, J., Fedová, D., Syrtček, K., Penningerová, L., Bračková, M. and Holanová, L. (1981). Antibody to parainfluenza virus types 1,2 and 3 in sera and nasal secretion of persons of different age. J. Hyg., Epidemiol., Microbiol., Immunol., 25, 65-70.

$\mathrm{Hu}, \mathrm{K}$. (1983). Detection of the respiratory syncytial virus antibody by ELISA. Chin. J. Microbiol. Immunol., 3, 311-314.

Ispolatova, A. W., Tzybulskaya, N. W., Olejnikova, E. W. and Popova, T. L. (1982). In Karpukhin, G. I. (ed.), Aetiology and Diagnostics of Influenza and other Acute Respiratory Diseases, Leningrad, pp. 80-83 (in Russian). 
Ispolatova, A. W., Kortchanova, N. L., Medvedinsky, V. V., Pluzhnikov, M. S., Al-Tamimi Fausi, A. and Schwartzman, Ya. S. (1983). Production of antibody to influenza virus by human lymphoid cells beyond organism. Byull. Eksp. Biol. Med., 7, 81-83 (in Russian).

Iwanova, L. A., Ketiladze, E. S., Polyakova, T. G., Tscheschik, S. G., Ursaki, L. P. and Elyseeva, S. I. (1986). Diagnostic significance of IgM, IgG specific antibodies in influenza and its combination with other acute respiratory viral diseases. Vopr. Okhr. Materin. Detstwa, 31, 40-43 (in Russian).

Jacobs, E., Bennewitz, A. and Bredt, W. (1986). Reaction pattern of human anti-Mycoplasma pneumoniae antibodies in enzyme-linked immunosorbent assays and immunoblotting. J. Clin. Microbiol., 23, 517-522.

Jennings, R., Smith, T. and Porter, C. W. (1981). Use of the enzyme linked immunosorbent assay (ELISA) for the estimation of serum antibodies in an influenza virus vaccine study. Med. Microbiol. Immunol., 169, 247-258.

Julkunen, I. (1984). Serological diagnosis of parainfluenza virus infections by enzyme immunoassay with special emphasis on purity of viral antigens. J. Med. Virol., 14, 177-187.

Julkunen, I., Kleemola, M. and Hovi, T. (1984). Serological diagnosis of influenza A and $B$ infections by enzyme immunoassay. Comparison with the complement fixation test. J. Virol. Methods, 9, 7-14.

Julkunen, I., Pyhaelae, R. and Hovi, T. (1985). Enzyme immunoassay, complement fixation and haemagglutination inhibition tests in the diagnosis of influenza $A$ virus infections. Purified haemagglutinin in subtype-specific diagnosis. J. Virol. Methods, 10, 75-84.

Kaul, T. N., Welliver, R. C. and Ogra, P. L. (1981). Comparison of fluorescent-antibody, neutralizing-antibody, and complement-enhanced neutralizing antibody assays for detection of serum antibody to respiratory syncytial virus. J. Clin. Microbiol., 13, 957-962.

Kessler, N., Suiphon, E. and Aymard, M. (1982). 4-eme Colloque sur la Grippe, Paris 20-22 avril 1982, Les Editions Inserm, Paris, pp. 45-59.

Kida, H., Brown, L. E. and Webster, R. G. (1982). Biological activity of monoclonal antibodies to operationally defined antigenic regions on the hemagglutinin molecule of an A/Seal/Massachusetts/1/80 (H7N7) influenza virus. Virology, 122, 38-47.

Konikova, R. E., Noskov, F. S. and Bayar, G. A. (1981). In Peradze, T. W. (ed.), Indirect Haemagglutination Reaction, Leningrad, pp. 49-31 (in Russian).

Kozhukhov, V. M., Zhilova, G. P., Kaschkin, A. P., Meringova, L. F. and Voyzehovsky, B. L. (1985). Use of enzyme immunoanalysis for the study of immune response in vaccinated against influenza and in convalescent patients. Vopr. Virusol., 30, 745-749 (in Russian).

Kühn, J., Wigand, R., Hammer, H. J., Bruch, P. and Adrian. T. (1984). Laboratoriumspraxis bei Adenoviren. XI. Nachweis von Hexon und Anti-HexonIgA im Konjunktivalsekret mit ELISA. Zentralbl. Bakteriol. Parasitenkd. Infektionskr. Hyg., A257, 426-432.

Kuzmin, Yu. A., Schamardin, V. A. and Karalnik, B. V. (1982). Application of amydol for preparation of erythrocyte diagnostics. Lab. Delo, 4, 245-247 (in Russian).

Lange, W. and Masihi, K. N. (1980). Enzyme-linked immunosorbent assay for the detection of influenza type-specific antibodies. Zentralbl. Bakteriol. Parasitenkd. Infektionskr. Hyg., 248, 27.

Lengyel, A., Ádám, E., Nász, J., Erdei, T. and Fachet, I. (1985). A sensitive method for detection of polyclonal and monoclonal antibodies against the adenovirus hexon. Acta Virol., 29, 362-372. 
Leshchinskaya, N. P., Pokrovskaya, E. E. and Schwartzman, Ya. S. (1985). In Actual Problems of Pediatric Pulmonology, Moscow, pp. 81-82.

Macnaughton, M. R. (1982). Occurrence and frequency of coronavirus infections in humans as determined by enzyme-linked immunosorbent assay. Infect. Immun., $38,419-423$.

Mancini, G., Donatelli, I., Arangio-Ruiz, G., Rozera, C. and Maccia, T. (1983). Comparison of haemagglutination-inhibition and single radial haemolysis techniques for detecting antibodies to influenza A and B viruses. J. Hyg., 91, 157-162.

Marquardt, W. W., Snyder, D. B. and Schlotthober, B. A. (1981). Detection and quantification of antibodies to infectious bronchitis virus by enzyme-linked immunosorbent assay. Avian Dis., 25, 713-722.

Mikuni, K. (1982). Study of respiratory-syncytial infection in children. Usage of enzyme immunosorbent assay for determination of antibody to respiratory syncytial virus. J. Kyorin. Med. Sci., 13, 335-344 (in Japanese).

Murphy, B. R., Phelan, M. A., Nelson, D. L., Yarchoan, R., Tierney, E. L., Alling, D. W. and Chanock, R. M. (1981). Hemagglutinin-specific enzyme-linked immunosorbent assay for antibodies to influenza $\mathrm{A}$ and $\mathrm{B}$ viruses. J. Clin. Microbiol., 13, 554-560.

Mykhailova, E. G., Djatchenko, N. S., Tarasyschyn, L. A., Rybalko, S. L. and Wantzak, N. P. (1986). Comparison of specificity and sensitivity of indirect passive haemagglutination and other techniques of antiadenoviral antibody determination. Mikrobiol. Zh., 6, 80-82 (in Russian).

Nandapalan, N., Routledge, E. and Toms, G. L. (1984). An enzyme-linked immunosorbent assay for IgG and IgA antibodies to respiratory syncytial virus in low dilutions of human serum and secretions. J. Med. Virol., 14, 285-294.

Nieto, A., Gayá, A., Moreno, C., Jansa, M. and Vives, J. (1986). Adsorptiondesorption of antigen to polystyrene plates used in ELISA. Ann. Inst. Pasteur/Immmunol., 137C, 161-172.

Noskov, F. S. (1985). In Peradze, T. W. and Halonen, P. (eds.), Immunological Diagnostics of Viral Infections, Medizina, Moscow, pp. 96-120 (in Russian).

Oxford, J. S., Yetts, R. and Schild, G. C. (1982). Quantitation and analysis of the specificity of post-immunization antibodies to influenza $B$ viruses using single radial haemolysis. J. Hyg., 88, 325-333.

Pettersson, R. F. (1980). Correlation between antibody titers to influenza A virus subtypes $\mathrm{H} 1 \mathrm{~N} 1$ and $\mathrm{H} 3 \mathrm{~N} 2$ as measured by hemagglutination-inhibition and haemolysis-in-gel tests. J. Infect. Dis., 142, 450-452.

Pitzurra, M., Bistoni, F., Pitzurra, L. and Marconi, P. (1983). Use of turkey red blood cells in the passive haemagglutination test for studying tetanus immunity. Bull. WHO, 61, 331-338.

Pokrovskaya, E. E. and Leshchinskaya, N. P. (1982). In Karpukhin, G. I. (ed.), Aetiology and Diagnostics of Influenza and other Acute Respiratory Diseases, Leningrad, pp. 67-82. (in Russian).

Pokrovskaya, E. E., Leshchinskaya, N. P., Orlov, A. W. and Schwartzman, Ya. S. (1983). In Schuratov, J. Ch. (ed.), Immunology of Viral and Mycoplasma Infections, Alma-Ata, pp. 70-75 (in Russian).

Profeta, M. and Ballerini, P. (1981). La prova de inhibizione dell'emoagglutinazione per virus influenzali con antigeni trattati con Tweenetere. Ann. Sclavo, 23, 530-642.

Pyhälä, R., Kleemola, M. and Visakorpi, R. (1985). The HI test modified by ether treatment in the sero-epidemiological surveillance of influenza B. J. Hyg., 94, 341-348. 
Richman, D. D., Cleveland, R. H., Redfield, D. C., Oxman, H. N. and Wahl, G. M. (1984). Rapid viral diagnosis. J. Infect. Dis., 149, 298-310.

Roggendorf, M., Wigand, R., Deinhardt, F. and Frösner, G. G. (1982). Enzyme-linked immunosorbent assay for acute adenovirus infection. J. Virol. Methods, 4, 27-35.

Rosmus, K., Griessmann, K. and Borkhardt, H. L. (1985). Untersuchungen zur Antigenbeladung und zur Lagerfähigkeit sensibilisierter Mikrotiterplatten für den Influenzavirus-ELISA. Z. Gesamte Hyg. Grenzgeb., 31, 649-650.

Rousseau, S. A. and Tettmar, R. E. (1985). The serological diagnosis of Mycoplasma pneumoniae infection: a comparison of complement fixation, haemagglutination and immunofluorescence. J. Hyg., 95, 345-352.

Roussel, C., Duverlie, G., Daniel, P. and Desmet, G. (1984). Application of the solid phase immunocaptation test to Paramyxovirus parainfluenzae and mumps infection diagnosis. Ann. Virol., E135, 269-276.

Sadykhova, F. E. (1985). Serological diagnosis of influenza and parainfluenza by means of radial haemolysis test. Vopr.Virusol., 5, 640 (in Russian).

Safford, I. S., Abbott, G. G. and Deimler, C. M. (1985). Evaluation of a rapid passive hemagglutination assay antibody: comparison to hemagglutination inhibition and a vaccine challenge study. J. Med. Virol., 17, 229-236.

Schefer, L. F., Korneeva, E. P., Konstantinova, I. I., Agafonova, L. M., Paramonova, M. S. and Zakharova, N. G. (1982). In Karpukhin, G. I. (ed.), Aetiology and Diagnostics of Influenza and other Acute Respiratory Diseases, Leningrad, pp. 47-51 (in Russian).

Schmidt, J., Adamczyk, B., Grühn, J., Oering, H., Süss, J., Vogt, K.-H., Brunnemann, H., Michaelis, I., Schmidt, S. and Kittlick, M. (1984). Vergleichende Bewertung von Influenzavirus-Antikörpertitern im Enzymimmunoassay und in anderen serologischen Reaktionen nach Schutzimpfung und bei Erkrankten. Z. Gesamte Hyg. Grenzgeb., 30, 436-441.

Schwartzman, Ya. S., Korneeva, E. P., Taros, L. Yu. and Naikhin, A. N. (1977). Serological diagnosis of influenza by means of indirect haemagglutination test. Acta Virol, 21, 228-233.

Shchekanova, S. M., Zotin, V. V., Lobanova, E. A. and Boldasov, V. H. (1982). In Karpukhin, G. I. (ed.), Aetiology and Diagnostics of Influenza and other Acute Respiratory Diseases, Leningrad, pp. 73-76 (in Russian).

Smorodintzev, A. A. (1985). In Peradze, T. W. and Halonen, P. (eds), Immunological Diagnosis of Viral Infections, Medizina, Moscow, pp. 49-76 (in Russian).

Steinitz, M. and Tamir, S. (1985). The coating of erythrocytes with detergentsolubilized molecules: a general method for improved coupling of antigens and antibodies. J. Immunol. Methods, 76, 27-38.

Tamendarova, N. T., Schuratov, I. Ch., Karalnyk, B. W. and Ansaryeva, K. G. (1985). Neuraminidase antigenic erythrocyte diagnosticum and its application for antibody determination to neuraminidase of influenza A viruses. Vopr. Virusol., 3, 369-373 (in Russian).

Taros, L. Yu. (1984). In Smorodintzev, A. A. (ed.), Influenza and its Prophylaxis, Medizina, Leningrad, pp. 72-84.

Tchaika, N. A. (1985). In Peradze, T. W. and Halonen, P. (eds), Immunological Diagnostics of Viral Infections, Medizina, Moscow, pp. 154-192 (in Russian).

Tchaika, N. A. and Gorbatchev, E. N. (1985). Application of agglutination reaction of sensitized latex for diagnosis of viral infections. Vopr. Virusol., 5, 516-523 (in Russian).

Tilton, R. L. (1985). An assessment of available rapid immunologic diagnostic methods. Diagn. Microbiol. Infect. Dis., 6(Suppl.), 25-32. 
Trofimova, M. G., Bykov, I. P. and Semenov, N. S. (1985). Sensitivity of indirect passive haemagglutination with an erythrocyte diagnosticum of respiratory syncytial virus. Vopr. Virusol., 2, 236-239 (in Russian).

Troisi, C. L. and Monto, A. S. (1981). Comparison of enzyme-linked immunosorbent assay and hemagglutination inhibition in a seroepidemiological study of influenza type C infection. J. Clin. Microbiol., 14, 516-521.

Turner, R., Lathey, J. L., Van Voris, L. P. and Belshe, R. B. (1982). Serological diagnosis of influenza $B$ virus infection: comparison of an enzyme-linked immunosorbent assay and the hemagglutination inhibition test. J. Clin. Microbiol., 15, 824-829.

Tzybulskaya, N. W., Popova, T. L., Ispolatova, L. M., Olejnikova, E. W., Karpukhin, G. I. and Schwartzman, Ya. S. (1983). Significance of secretory antibodies in resistance to influenza infection and prevention of virus distribution. Zh. Mikrobiol., Epidemiol., Immunobiol., 7, 81-84 (in Russian).

Van der Logt, J. T. M., Van Loon, A. M. and Van der Veen, J. (1982). Detection of parainfluenza IgM antibody by hemadsorption immunosorbent technique. $J$. Med. Virol., 10, 213-221.

Van der Logt, J. T. M., Van Loon, A. M. and Van der Veen, J. (1985). Diagnosis of parainfluenza virus infection in children and older patients by detection of specific IgM antibody. J. Med. Virol., 16, 191-199.

Van Voris, L. P., Betts, R. F., Menegus, M. A., Murphy, B. R., Roth, F. K. and Douglas, R. G., Jr. (1985). Serological diagnosis of influenza A/USSR/77 H1N1 infection: value of ELISA compared to other antibody techniques. J. Med. Virol., 16, 315-320.

Vaur, L., Agut, H., Garbarg-Chendon, A., Prud'Homme de Saint-Maur, G., Nicolas, J. C. and Bricout, F. (1986). Simplified enzyme-linked immunosorbent assay for specific antibodies to respiratory syncytial virus. J. Clin. Microbiol., 24, 596-599.

Voller, A. and Bidwell, D. (1985). In Della-Porta, A. J. (ed.), Veterinary Virus Diseases: their Significance in South-East Asia and the Western Pacific, Academic Press, Sydney, pp. 61-70.

Wasilieva, W. I., Zakstelskaya, L. Ya., Goworkova, E. A., Rusakova, E. B., Alexeenkova, L. I., Gotwyanskaya, T. P. and Kaschlyaeva, T. K. (1985). Study of population immune structure to influenza C virus. Vopr. Virusol., 30, 661-664 (in Russian).

WHO (1984). Simplified Immunodiagnostics: Conclusions and Recommendations of WHO Meeting, Geneva, June 1983. Bull. WHO, 62, 23-37 (in Russian).

Yankina, N. F., Rasstegaeva, T. D. and Waneeva, L. I. (1984). Conjugate of immunoglobulin with peroxidase and method of thereof preparation. Inventor's Certificate USSR N 1071960, IPC: GO1N33/54,A61K37/48,A61K39/395. Otkrytiya, Isobreteniya, 5.

Yurkova, G. E. (1982). In Karpukhin, G. I. (ed.), Aetiology and Diagnostics of Influenza and other Acute Respiratory Diseases, Leningrad, pp. 61-66 (in Russian).

Yurkova, G. E., Sominina, A. A., Koroleva, O. A. and Wasilieva, R. I. (1983). Application of radial haemolysis reaction in gel for influenza and RS-infection diagnosis. In Thesis of the Second Congress of Infectionists of Ukrainian Soviet Socialist Republic, Kiev, pp. 128-129 (in Russian).

Zhurov, S. A. and Waserin, Yu. I. (1985). Erythrocyte test-preparations for standardization of fluorescent antibodies and serological diagnosis of influenza. Zh. Mikrobiol. Epidemiol. Immunobiol., 4, 81-85 (in Russian). 